\title{
Iskolaközösségi gyermek-egészségfejlesztési és elhízás- prevenciós beavatkozás egy klaszter randomizált vizsgálata: a Fun 'n healthy in Moreland! projekt eredményei
}

\author{
Cluster randomised trial of a school-community child health promotion \\ and obesity prevention intervention: findings from the evaluation of \\ fun`n healthy in Moreland!
}

Ismertető: $\quad$ Maczali Katalin $\square$

Állami Egészségügyi Ellátó Központ

Szerzők: Miller V, Mente A, Dehghan M et al.

Megjelenés: The Lancet, Published Online August 29, 2017.

DOI: http://dx.doi.org/10.1016/S0140-6736(17)32253-5

Beküldve: 2017.09.13.

doi: $10.24365 /$ ef.v58i3.183

Kulcsszavak: gyermekkori elhízás; prevenció; iskolai egészségfejlesztés; klaszter randomizált vizsgálat

\section{ÖSSZEFOGLALÁS}

A gyermekkori elhízás kedvezőtlen pszichológiai és fiziológiai következményekkel köthető össze, ezért népegészségügyi szempontból is fontos egy hatékony elhízást megelőző intervenció kidolgozása. Ilyenre példa, a „Fun 'n healthy in Moreland", amely a gyermekkori elhízások csökkentését, az iskolai szabályozások és környezet javítását, a fizikai aktivitás növelését, a szülők bevonását, illetve az egészségmagatartás és gyermekjólét fejlesztését célozza meg Ausztráliában, Melbourne egyik külvárosi részén.

Az intervenciót egy egyetemi kutatócsoport és a helyi közösség egészségügyi-ellátója dolgozta ki, melyben vizsgálták a fizikai, környezeti, szociális, viselke- dési és pénzügyi hatásokat és eredményeket. A résztvevők 24 általános iskola - 5-12 év közötti, véletlenszerűen kiválasztott - diákjai, akikből 1426 fő az intervencióba bevont iskolákban, 1539 fő pedig a kontroll iskolákban tanult.

A 3,5 éves intervenció eredményei alapján, az egészséges testsúly előfordulása és a napi zöldség/gyümölcs bevitel mennyisége nagyobb volt a kontroll iskola diákjaihoz képest, illetve nagyobb valószínúséggel fogyasztottak vizet a cukros üdítők/szörpök helyett, a programban résztvevő diákok, azonban a BMI (testtömegindex) adatokban nem történt szignifikáns változás. Mindemellett a program során fejlődtek az iskolai szabályozások, jobban bevonták a szülőket a programokba, és javult a gyermekek önértékelt egészsége.

\section{KULCSÜZENET A SZAKEMBEREK SZÁMÁRA}

A népegészség szempontjából fontos a gyermekkori elhízás megelőzése. Ez komplex intervenciót igényel, mely során szükséges az iskolát, mint mikroközösséget, és a szülőket egyaránt bevonni a folyamatba, amely során egészségesebb magatartásra ösztönözhetjük a diákokat, valamint azok közvetlen és közvetett környezetét. 